Ann. Biol. anim. Bioch. Biophys., I973, 13 (I), I-5.

\title{
THE EFFECT OF THE RATIO OF DILUTION OF RAM SEMEN IN DIFFERENT DILUENTS ON THE CONCEPTION RATE ( $\left.{ }^{1}\right)$
}

\author{
D. AMIR, H. SCHINDLER, E. EYAL, A. R. LEHRER \\ and Ora KEMPENICH-PINTO \\ The Volcani Center, Agricultural Research Organization, \\ Bet Dagan (Israel)
}

\section{SUMMARY}

Dilution of ram semen at a ratio of $\mathbf{I}$ : I did not lower the conception rate in comparison with undiluted semen. Dilution at a ratio of $I:$ Io in a yolk-citrate-glycine-fructose diluent with or without catalase considerably reduced the conception rate, whereas in a skim milk diluent this treatment resulted in the same conception rate as did undiluted semen or semen diluted I : $\mathbf{~}$.

\section{INTRODUCTION}

The literature on the effect of the ratio of dilution of ram semen on the conception rate, as reviewed by EMmENS and RoBINSon (I962), does not show uniform results : whereas in a number of studies ram semen could be diluted without loss of fertility, other authors found that dilution of more than $I: I$ to I : Io caused a severe drop in fertility. In most of these studies as well as in more recent works (Pop, Salajan and Iozon, Ig64; AAMdal, FJOESNE and Hovland, I967; SEMKov and Kolev, I966), the effect of dilution cannot be separated from that of the inseminated sperm number which was reduced by the increased dilution ratio. With the same number of spermatozoa per insemination dose, JONES, MARTIN and LAPWOOD (I969) and LAPWOOD, MARTIN and ENTwisTLE (I972) found that a ten-fold dilution of ram semen with skim milk reduced the conception rate in comparison with undiluted semen. In view of the importance of dilution for the

(') Contribution from The Volcani Center, Agricultural Research Organization, Bet Dagan, Israel. I97 I Series, No. 2033-E. 
development of $\mathrm{AI}$, the influence of the dilution ratio of ram semen on the conception rate was investigated further. The experiments were carried out in a total of seven flocks during a two-week period at the beginning of three consecutive breeding seasons.

\section{MATERIALS AND METHODS}

\section{Semen collection and dilution}

Ejaculates, collected from $A$ wassi rams with an artificial vagina, with strong wave motion and a sperm concentration of $2.5-5.5 \times 10^{9} \mathrm{cells} / \mathrm{ml}$, with the majority of the ejaculates having a sperm concentration of $3.5-4.5 \times 10^{9}$ cells $/ \mathrm{ml}$, were used. Each ejaculate was split into two parts, one to be used undiluted and the other for immediate dilution with the desired diluent. Inseminations were made within $30 \mathrm{mn}$ after collection, during which time both portions of the semen were kept at $25^{\circ}-30^{\circ} \mathrm{C}$.

\section{Diluents}

In the first season, a yolk-citrate-glycine-fructose (YCGF) diluent adapted from STowER and Bud-Husaim (1957), as described elsewhere (AMIR and SchindLER, I967), was used. In the second season the same diluent was supplemented with 60 IU of catalase (BDH) per ml. In the third season, reconstituted skim milk (Regilait, France-Lait) containing $0.3 \mathrm{~g}$ sulfanilamide, roo,000 units of penicillin and $0 . \mathrm{I} \mathrm{g}$ of streptomycin per IOO ml (COLAS, DaUzier, Courot, OrTaVANT and SignORET, 1968), served as diluent.

\section{Dilution ratio and semen dose}

Undiluted semen and semen which had been diluted at ratios of $\mathrm{I}: \mathrm{I}$ and $\mathrm{I}$ : Io were used for inseminations. Since in practice very small volumes cannot be handled with accuracy and because of lack of information as to the effect of large volumes (INSKEEP and COOKE, I968) and their possible adverse effects (TERRILL, I968), the experiment was limited to the following amounts of semen : $0.05 \mathrm{ml}$ of undiluted semen (control); $0.05 \mathrm{ml}$ and $0.10 \mathrm{ml}$ of semen diluted at a ratio of $I: I$, and $0.25 \mathrm{ml}$ of semen diluted at a ratio of $I: 10$. These treatments were given to each ejaculate and similar numbers of ewes were inseminated with each treatment.

This experimental design allowed us, within each of the three insemination seasons, to compare the effect of the different dilution ratios using doses of sperm suspensions which were equivalent to either $0.05 \mathrm{ml}$ or $0.025 \mathrm{ml}$ undiluted semen. In no semen dose was the number of spermatozoa below I20 $\times 10^{6}$, which had been reported (SALAMON, 1962) to be adequate for maximum conception rate. In most cases this number was exceeded.

\section{Handling of ewes}

In the first season heat detection (with aproned rams) was carried out once a day and two inseminations per oestrus were given, one immediately after heat detection and the other about 12 hours later. In the second and third seasons heat detections were carried out at I 2 hour intervals and one single insemination per oestrus was given, about 12 hours after heat was first detected.

\section{RESULTS AND DISCUSSION}

The results are presented in table I. Ewes which did not become pregnant after two or more additional oestrous periods are not included in the results. It can be seen that in all diluents, semen diluted at a ratio of $I: I$ was as fertile as undiluted semen. Reducing the sperm number to half of that in the control (undiluted 
DIIUTION AND FERTILITY OF RAM SEMEN

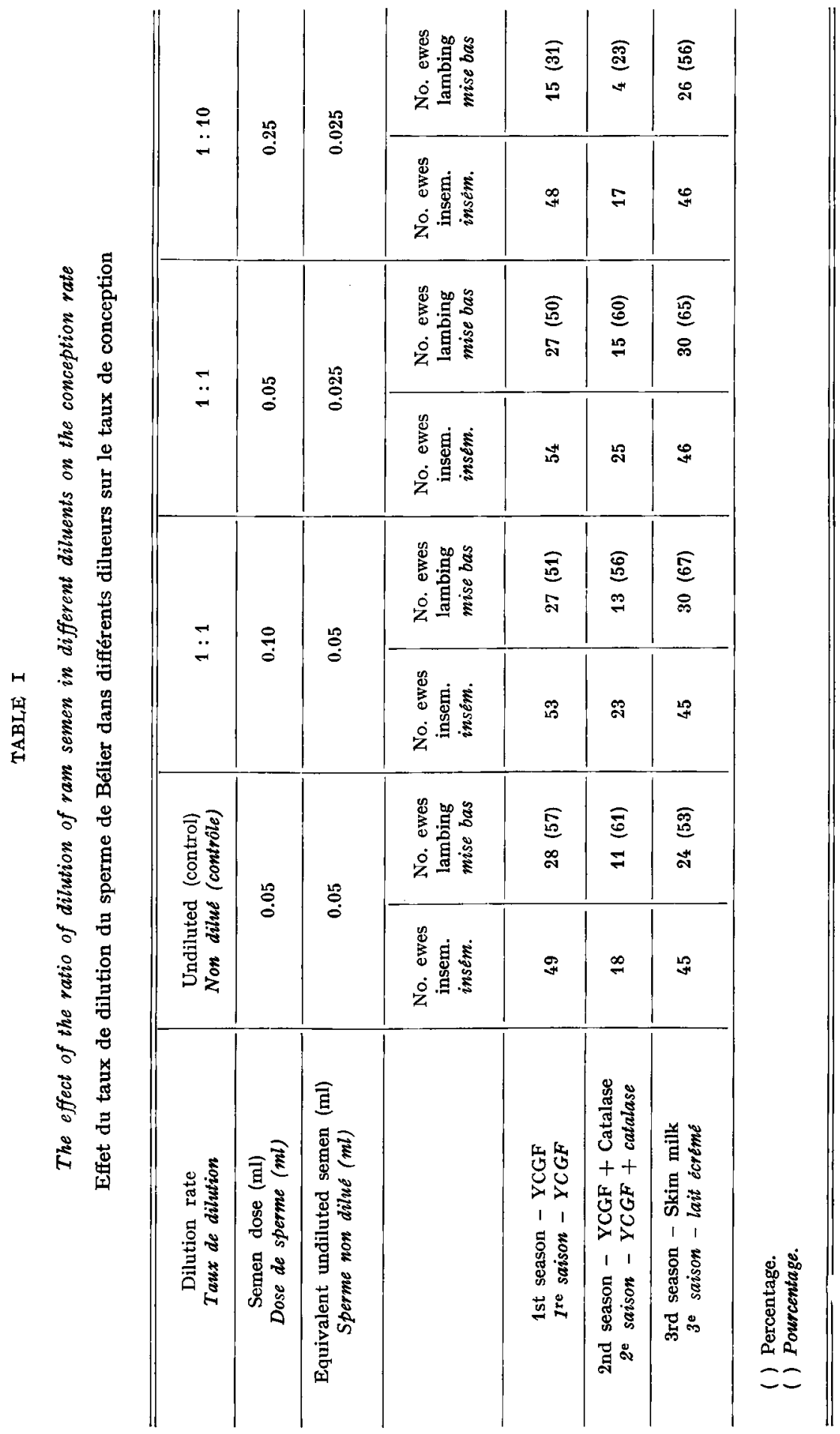


semen), did not lower the conception rate when the dilution ratio was kept at I : I. The I : Io dilution ratio in the YCGF diluent, with or without catalase, reduced the conception rate in comparison with the results obtained when the equivalent of raw semen was used at a dilution ratio of $\mathrm{I}: \mathrm{I}$. With the skim milk diluent the results obtained at the $I$ : Io dilution ratio were similar to those obtained with the other treatments. This result also shows that a volume of $0.25 \mathrm{ml}$ was no less effective than smaller volumes. The discrepancy between the present results and those reported by JONES et al. (I969) and LAPWOOD et al. (I972) may possibly be explained by the different brands of skim milk powders used.

The decrease in the conception rate resulting from inseminations with semen diluted $I:$ Io in the YCGF diluent may be due to the damage to the acrosome occurring in this diluent. Preliminary light and electron microscope studies (AmIR, SCHINDLER, BRODA and BEN-DAvid, unpublished) indicated that the percentage of spermatozoa with a damaged acrosome increased with increasing dilution ratio in this diluent, although those abnormalities were distinguishable only after incubation of the sperm suspensions at $37^{\circ} \mathrm{C}$. No such an effect was found when the skim milk medium was used, even at very high dilution ratios.

Reçu pour publication en octobre 1972.

\title{
ACKNOWLEDGEMENTS
}

This investigation was supported by a grant from the United States Department of Agriculture under P. L. 480 . The authors are indebted to A. Schaer and U. Lilienfeld of the Agricultural Extension Service for their co-operation and advice. The skillful help of the flock owners is gratefully acknowledged.

\author{
RÉSUMÉ \\ INFLUENCE DU DILUEUR ET DU TAUX DE DILUTION \\ SUR LA FERTILITÉ DU SPERME DE BÉLIER
}

469 Brebis $A$ wassi ont été inséminées durant trois saisons d'insémination, avec du sperme non dilué (témoin) ou dilué soit dans un milieu composé de jaune d'ouf et d'un tampon de citrate, glycine et fructose (YCGF), soit dans du lait de Vache écrémé. Les taux de dilution employés sont de $I: x$ et de $r:$ ro.

Un taux de dilution de I : I dans les deux milieux ne réduit pas le pourcentage de mises bas par rapport au groupe témoin. Un taux de dilution de I : Io dans le YCGF réduit considérablement le pourcentage de mises bas, même après addition de catalase dans le milieu. Par contre, le lait de Vache écrémé comme milieu de dilution, a donné les mêmes résultats que le sperme non dilué quel que soit le taux de dilution.

\section{REFERENCES}

aamdal, J., FJoesne H., Hovland M., 1967. Experiments with insemination of sheep. Anim. Breed. A bstr., 37, 574-

Amir D., Schindler H., I967. Influence of lactate on the rates of fructolysis and respiration in ram spermatozoa. J. Reprod. Fert., 14, 121-127. 
Colas G., Dauzier L., Courot M., Ortavant R., Signoret J.-P., ig68. Résultats obtenus au cours de l'étude de quelques facteurs importants de l'insémination artificielle ovine. Ann. Zootech., 17, $45-57$.

Emmens C. W., Robinson T. J., 1962. Artificial insemination in the sheep. Ch. 12 in The Semen of Animals and Artificial Insemination. J. P. Maule, Ed. Commonwealth Agricultural Bureaux, Farnham Royal.

I NSKeEP E. K., Cooke C. E., I968. Artificial insemination and preservation of semen. Proc. Symp. Physiol. Reprod. in Sheep, Oklahoma State Univ., Stillwater, Okla., July 26-27, 1968. p. I62-180.

Jones R. C., Martin I. C. A., Lapwood K. R., rg69. Studies on the artificial insemination of sheep : The effects on fertility of diluting ram semen, stage of cstrus of the ewe at insemination, and injection of synthetic oxytocin. Aust. J. agric. Res, 20, I4I-I50.

Lapwood K. R., Martin I. C. A., Entwistle K. W., I972. The fertility of Merino ewes artificially inseminated with semen diluted in solutions based on skim milk, glucose or ribose. Aust. J. agric. Res., 23, 457-466.

Pop E., Salajan G., Iozon D., I964. Studies on increasing the rate of dilution of ram semen. Anim. Breed. Abstr., 32, 3 ro8.

Salamon S., rg62. Studies on the artificial insemination of Merino sheep. III. The effect of frequent ejaculation on semen characteristics and fertilizing capacity. Aust. J. agric. Res., 13, II37-II50.

Semkov M, Kolev A, 1966 Conception in ewes inseminated with various numbers of spermatozoa. Anim Breed. Abstr., 35, 2688.

Stower J., Bud-Husaim P., r957. Conception rates with bull semen diluted in a glycerolized glycineegg yolk-fructose buffer. J. agric. Sci. Camb., 49, $220-222$.

TERrili C. E., 1968. Sheep and Goats. Ch. ro in The Artificial Insemination of Farm Animals. E. J. Perry, Ed. Rutgers University Press, New Brunswick, N. J. 